\title{
Effect of Rates and Methods of N Application on Growth, Fruit Yield and Mineral Content of Manzanillo Olive Trees
}

\author{
A. I. Abou-Amer \\ Soil Fertility and Microbiology Department, Water Resources \\ and Desert Soils Division, Desert Research Center (DRC), \\ Cairo, Egypt.
}

\begin{abstract}
$\mathbf{T}$ HE EFFECT of rates and methods of $\mathrm{N}$ application on growth and fruit yield as well as mineral content of Manzanillo olive trees was investigated during two successive seasons 2008/2009 and 2009/2010. This study was carried out at Siwa Oasis in the Western Desert of Egypt between longitude $25^{\circ} 33^{\prime}$ and $35^{\circ} 81^{\prime} \mathrm{E}$ and latitudes $29^{\circ} 10^{\prime}$ and $37^{\circ} 82^{\prime} \mathrm{N}$. Nitrogen fertilizer rates and application methods included of; 1) average recommended doses of soil application of $800 \mathrm{~g} \mathrm{~N} /$ tree, 2) foliar $1 \%$ urea alone, 3) foliar $1 \%$ urea $+100 \%$ of soil $\mathrm{N}$ dose, 4) foliar $1 \%$ urea $+75 \%$ of soil $\mathrm{N}, 5)$ foliar $1 \%$ urea $+50 \%$ of soil $\mathrm{N}, 6)$ foliar $3 \%$ urea alone, 7) foliar $3 \%$ urea $+100 \%$ of soil $\mathrm{N}$ dose, 8 ) foliar $3 \%$ urea $+75 \%$ of soil $\mathrm{N}$, and 9) foliar $3 \%$ urea $+50 \%$ of soil $\mathrm{N}$, beside control treatment (without $\mathrm{N}$ ). The obtained results showed a significant positive response of olive trees to all $\mathrm{N}$ fertilizer rates and methods as was reflected on growth parameters, fruit and oil yields as well as mineral content of plant and soil compared to the control treatment. The combined applied of $\mathrm{N}$ soil of $100 \% \mathrm{~N}$ dose + foliar $1 \%$ urea significantly achieve the best growth parameters, fruit oil content with the highest economic fruit yield. It is worthy of mentioning that this treatment was also accompanied by increased mineral content of soil and plant. Noteworthy is that the sprayed urea of $3 \%+100 \%$ soil dose gave an increased vegetative growth of trees at the expense of fruiting and oil content. Therefore, it could be recommended to use integrated of $800 \mathrm{~g}$ N/tree as soil application with urea foliar spray of $1 \%$ for Manzanillo olive trees under conditions of Siwa Oasis and trees planted under the same conditions.
\end{abstract}

Keywords: N fertilizer, Foliar urea, Manzanillo olive trees, Fruit yield, Oil yield, Mineral content.

Nitrogen $(\mathrm{N})$ is the most important element for plant growth and development. Consequently, application of $\mathrm{N}$ fertilizers had the most significant effect in increasing crop production (Mengel and Kirby, 1987). Application of $\mathrm{N}$ is the main aspect of the olive orchard fertilization requiring annual soil and leaf applications. However, the over application of $\mathrm{N}$ not only increases production 
costs, but may also affect fruit quality and result in $\mathrm{N}$ contamination of the environment (López-Granados et al., 2004). Therefore, high cost of $\mathrm{N}$ fertilizer application has become necessary to increasing efficiency of $\mathrm{N}$ use by foliar together with soil application. Accordingly, foliar spray is a widespread application method used in olive orchards to correct frequent deficient level of $\mathrm{N}$ in olive trees (Pastor, 2005). Hence, mineral feeding is one of the main tools to improve fruit yield and quality (Payvandi et al., 2001). Urea [CO $\left.\left(\mathrm{CH}_{2}\right)_{2}\right]$ is an economic and easily available fertilizer and a fast source of $\mathrm{N}$ when it is applied as a foliar spray. Also, urea is commonly used for foliar fertilizer applications because it is nonpolar, highly soluble in water, and can rapidly and efficiently absorb by leaves (Bondada et al., 2001). On the other hand, application of $\mathrm{N}$ to soil is the traditional method to supply $\mathrm{N}$ to plants, it effectively improves plant growth, while soil $\mathrm{N}$ application usually has a low recovery and high risk of losses to leaching (Dinnes et al., 2002). Therefore, methods of increasing N use efficiency and reducing $\mathrm{N}$ loss is important for fertilization management in orchards (Shufu et al., 2005). Moreover, applications of $\mathrm{N}$ as foliar applications have a higher recovery rate than soil applications (Rosecrance et al., 1998). However, it is still believed that soil $\mathrm{N}$ applications cannot be completely substituted for by foliar $\mathrm{N}$ applications (Mengel, 2002). It is possible that the integration of soil and foliar $\mathrm{N}$ applications may be a more efficient use of $\mathrm{N}$ and reduces $\mathrm{N}$ loss (Khemira et.al., 1998). The timing and method of $\mathrm{N}$ application (e.g., soil versus foliar $\mathrm{N}$ application) during the growing season may influence $\mathrm{N}$ uptake as well as plant growth and function. Also, the foliar application is helpful to satisfy plant requirement and has a high efficiency (Inglese et al., 2002). So, the method of application plays a key role in fertilizer efficiency, especially for $\mathrm{N}$, particularly in the poor sandy soils. In addition to, foliar application of urea is an effective method of replacing $\mathrm{N}$ application method soils (Sanchez and Fernandez, 2002).

In Egypt, olive trees are widely planted in oases and newly reclaimed soils mostly in sandy soil. Accordingly, the production of olive in these areas is generally low due to the poor soil fertility and low water holding capacity of the soil (Hegazi et al., 2007). Also, the Spanish cv. Manzanillo is the most important commercial variety in the world and good for table olives and oil production. However, increasing olive tree productivity under desert conditions must be based on appropriate technical and economic management due to the natural resources scarcity (Osman, 2010). In this respect, several researchers have shown that the recommended doses of $\mathrm{N}$ fertilizer for olive trees at rates of 500 (low rate), 800 (medium rate) and $1000 \mathrm{gm}$ (high rate) of $\mathrm{N}$ per tree (Fernandez and Marin, 1999, Abou-Amer, 2007 and Abdel-Hameed, 2002). However, can be use of $800 \mathrm{~g} \mathrm{~N} /$ tree as average of these rates. Therefore, the present investigation was conducted to study the effect of rates and methods of $\mathrm{N}$ application on growth, fruit yield and fruit oil as well as mineral content of Manzanillo olive trees under Siwa Oasis conditions. 


\section{Material and Methods}

A field experiment was carried out at Per El-Kaaf region in east Siwa Oasis between longitude $25^{\circ} 33^{\prime}$ and $35^{\circ} 81^{\prime} \mathrm{E}$ and latitudes $29^{\circ} 10^{\prime}$ and $37^{\circ} 82^{\prime} \mathrm{N}$, during two successive seasons of 2008/2009 and 2009/2010, to study the effect of rates and methods of $\mathrm{N}$ application on growth, fruit yield and mineral content of Manzanillo olive trees. The experiment soil was sandy in texture with low fertility status, as shown in Table 1 . The soil of the experimental field was irrigated by flood irrigation system using underground water. The study started at last November 2008 on Manzanillo olive cultivar of 10 years old. The selected trees were approximately similar in growth vigor and the trees were $5 \times 6 \mathrm{~m}$ apart. Nitrogen fertilizer rates and application methods included of, 1) average recommended doses of soil application at $800 \mathrm{~g} \mathrm{~N} /$ tree, 2) foliar $1 \%$ urea alone, 3) foliar $1 \%$ urea $+100 \%$ of soil $\mathrm{N}$ dose, 4 ) foliar $1 \%$ urea $+75 \%$ of soil $\mathrm{N}, 5$ ) foliar $1 \%$ urea $+50 \%$ of soil $\mathrm{N}, 6$ ) foliar $3 \%$ urea alone, 7) foliar $3 \%$ urea + $100 \%$ of soil $\mathrm{N}$ dose, 8 ) foliar $3 \%$ urea $+75 \%$ of soil $\mathrm{N}$ and 9 ) foliar $3 \%$ urea + $50 \%$ of soil $\mathrm{N}$, beside control treatment (without $\mathrm{N}$ ). Soil application of $\mathrm{N}$ was applied in the form of ammonium nitrate $(33 \% \mathrm{~N})$. Whereas, foliar applied of $\mathrm{N}$ was in the form of urea $(46 \% \mathrm{~N})$. Regarding time, $\mathrm{N}$ was applied to soil in three equal doses at February, June, and August. $\mathrm{N}$ foliar (1\% and 3\% urea) was applied to trees in three equal splits by spraying urea solution of 20 liter per tree at the same times with soil $\mathrm{N}$ application in each season, as shown in Table 2. In addition, all the olive trees received $\mathrm{P}, \mathrm{K}, \mathrm{Fe}, \mathrm{Mn}, \mathrm{Zn}$ and $\mathrm{OM}$ fertilizers. $\mathrm{P}$ fertilizer (300g $\mathrm{P}_{2} \mathrm{O}_{5} /$ tree) was applied mixed with $25 \mathrm{~kg} /$ tree of organic manure in the second week of December every season. Also, fertilizer of $\mathrm{K}\left(750 \mathrm{~g} \mathrm{~K}_{2} \mathrm{O}\right.$ / tree) applied in three equal doses at the same times with $\mathrm{N}$ application. Micronutrients (i.e., mixture of $\mathrm{Fe}, \mathrm{Mn}$ and $\mathrm{Zn}$ ) at the ratio of 1: 1: 2 from each, respectively) were applied at April and June to all treatments.

In each olive tree, 20 shoots of one year-old were selected at random and labeled. The chosen shoots were even distributed into the four main directions, i.e., five shoots in each main direction. The measurements included growth parameters, i.e., number of shoots per twig, shoot length and numbers of leaves per shoot, according to Haggag (1996). Fruit yield of olive trees were picked on mid of October and recorded in $\mathrm{kg} /$ tree. Olive leaves were sampled in August every season in order to follow up plant nutritional level. Fruit oil was extracted from fruit dry flesh using Soxhelt of petroleum ether at $60-80{ }^{\circ} \mathrm{C}$. After that, oil yield was measured as percentage and total yield in kg per tree. Nitrogen content of the olive leaves was determined as well as fruit oil content according to AOAC (2000). 
TABLE 1. Some physical and chemical properties of the investigated soil.

\begin{tabular}{|c|c|c|c|c|c|}
\hline \multirow{3}{*}{ Soil properties } & \multicolumn{2}{|c|}{ Depth (cm) } & \multicolumn{3}{|c|}{ Available macronutrients $\left(\mathrm{mg} / \mathrm{Kg}^{-1}\right)$} \\
\hline & \multirow{2}{*}{$0-30$} & \multirow{2}{*}{$30-60$} & \multirow{2}{*}{ Element } & \multicolumn{2}{|c|}{ Depth $(\mathrm{cm})$} \\
\hline & & & & $0-30$ & $30-60$ \\
\hline $\mathrm{pH}$ & 7.86 & 7.83 & $\mathrm{~N}$ & 14.50 & 6.80 \\
\hline $\mathrm{EC} \mathrm{dS/m}$ & 3.51 & 3.22 & $P$ & 3.00 & 1.63 \\
\hline OM \% & 0.79 & 0.43 & $\mathrm{~K}$ & 53.30 & 42.51 \\
\hline $\mathrm{CaCO}_{3} \%$ & 6.12 & 4.36 & \multicolumn{3}{|c|}{ Available micronutrients (ppm) } \\
\hline Sand $\%$ & 86.50 & 85.60 & $\mathrm{Fe}$ & 10.40 & 4.62 \\
\hline Silt $\%$ & 9.30 & 9.80 & $\mathrm{Mn}$ & 7.38 & 3.50 \\
\hline Clay $\%$ & 4.24 & 4.56 & $\mathrm{Zn}$ & 0.49 & 0.21 \\
\hline Texture & Sand & Sand & $\mathrm{Cu}$ & 0.18 & 0.11 \\
\hline
\end{tabular}

Concerning soil orchard, four random soil samples from main directions of each tree were taken at 0-30 and 30-60 cm depth after the harvest in the two seasons. Soil samples were mixed, air-dried and ground to pass a 2-mm sieve. Available major (N, P and $\mathrm{K}$ ) and minor elements (Fe, $\mathrm{Mn}, \mathrm{Zn}$ and $\mathrm{Cu}$ ) were determined according to Black et al. (1982).

TABLE 2. Fertilizer treatments to olive trees for the two seasons of 2009 and 2010.

\begin{tabular}{|l|l|l|l|}
\hline No. & \multicolumn{1}{|c|}{ Treatments } & \multicolumn{1}{|c|}{ Rates } & \multicolumn{1}{|c|}{$\begin{array}{c}\text { Methods of } \\
\text { application }\end{array}$} \\
\hline 1 & Control & without N & None \\
\hline 2 & Soil N (average recommended doses) & $800 \mathrm{~g} \mathrm{~N} /$ tree & Soil application \\
\hline 3 & Foliar 1\% urea & $1 \%$ urea & Foliar application \\
\hline 4 & Soil N +1\% urea & $800 \mathrm{~g} \mathrm{~N}+1 \%$ & Soil + foliar \\
\hline 5 & $75 \%$ soil N+1\% urea & $600 \mathrm{~g} \mathrm{~N}+1 \%$ & Soil + foliar \\
\hline 6 & $50 \%$ soil N+1\% urea & $400 \mathrm{~g} \mathrm{~N}+1 \%$ & Soil + foliar \\
\hline 7 & Foliar $3 \% \mathrm{~N}$ urea & $3 \%$ urea & Foliar application \\
\hline 8 & Soil N $+3 \%$ urea & $800 \mathrm{~g} \mathrm{~N}+3 \%$ & Soil + foliar \\
\hline 9 & $75 \%$ soil N+3\% urea & $600 \mathrm{~g} \mathrm{~N}+3 \%$ & Soil + foliar \\
\hline 10 & $50 \%$ soil N+3\% urea & $400 \mathrm{~g} \mathrm{~N}+3 \%$ & Soil + foliar \\
\hline
\end{tabular}

With regard to statistical design, the treatments were arranged in completely randomized block design_with three replicates for each treatment. Data set was analyzed a whole data set to verify the significant differences among the means of these treatments. In addition, the combined treatments between the soil and foliar applied $\mathrm{N}$ were analyzed as factorial treatments to show the effects of both soil and foliar applied of $\mathrm{N}$ and the interaction between them as well. Mean separation was obtained using the LSD at 5\% level of significance according to Gomez and Gomez (1984).

Egypt. J. Soil Sci. 53, No.2 (2013) 


\section{Results and Discussion}

\section{Growth parameters}

Vegetative growth parameters (Table 3), i.e., number of shoots per twig, shoot length and number of leaves per shoot was significantly increased by $\mathrm{N}$ applications when compared with the control treatment in both seasons. Also, growth parameters were markedly increased with increasing the amount of $\mathrm{N}$ application in all treatments. In addition, shoot length and number of leaves per shoot were significantly increased with $\mathrm{N}$ soil application compared to $\mathrm{N}$ foliar sprayed alone at a concentration of $1 \%$ or $3 \%$ urea. This may be due to soil $\mathrm{N}$ dose was sufficient to trees compared to foliar $\mathrm{N}$ dose.

TABLE 3. Effect of $\mathbf{N}$ fertilization treatments on growth parameters of Manzanillo olive trees.

\begin{tabular}{|c|c|c|c|c|c|c|c|c|c|}
\hline \multirow{2}{*}{ Treatments } & \multicolumn{3}{|c|}{$\begin{array}{l}\text { Number of shoots / } \\
\text { twig }\end{array}$} & \multicolumn{3}{|c|}{ Shoot length (cm) } & \multicolumn{3}{|c|}{ No. of leaves / shoot } \\
\hline & $\begin{array}{l}\text { Season } \\
2009\end{array}$ & $\begin{array}{l}\text { Season } \\
2010\end{array}$ & Mean & $\begin{array}{l}\text { Season } \\
2009\end{array}$ & $\begin{array}{l}\text { Season } \\
2010\end{array}$ & Mean & $\begin{array}{l}\text { Season } \\
2009\end{array}$ & $\begin{array}{l}\text { Season } \\
2010\end{array}$ & Mean \\
\hline Control & 1.94 & 2.01 & 1.98 & 10.16 & 11.03 & 10.59 & 11.08 & 11.93 & 11.50 \\
\hline Soil N & 2.25 & 2.43 & 2.34 & 12.90 & 13.50 & 13.20 & 13.80 & 14.20 & 14.00 \\
\hline Foliar $1 \%$ urea & 2.31 & 2.49 & 2.40 & 11.56 & 12.00 & 11.78 & 12.43 & 13.02 & 12.73 \\
\hline Soil $\mathrm{N}+1 \%$ urea & 2.39 & 2.59 & 2.49 & 13.39 & 13.80 & 13.60 & 14.00 & 14.70 & 14.35 \\
\hline $\begin{array}{lll}50 \% & \text { soil } & \mathrm{N}+1 \% \\
\text { urea } & & \\
\end{array}$ & 2.29 & 2.43 & 2.36 & 11.90 & 12.16 & 12.03 & 12.45 & 13.20 & 12.82 \\
\hline $\begin{array}{lll}75 \% & \text { soil } & \mathrm{N}+1 \% \\
\text { urea } & & \\
\end{array}$ & 2.32 & 2.52 & 2.42 & 12.24 & 12.43 & 12.34 & 12.80 & 13.50 & 13.15 \\
\hline Foliar $3 \% \mathrm{~N}$ urea & 2.36 & 2.50 & 2.43 & 12.24 & 12.52 & 12.38 & 12.90 & 13.54 & 13.22 \\
\hline Soil $\mathrm{N}+3 \%$ urea & 2.53 & 2.83 & 2.68 & 14.20 & 13.79 & 13.99 & 14.50 & 15.60 & 15.05 \\
\hline $\begin{array}{lll}50 \% & \text { soil } & \mathrm{N}+3 \% \\
\text { urea } & & \\
\end{array}$ & 2.32 & 2.48 & 2.40 & 12.50 & 12.81 & 12.66 & 13.32 & 13.94 & 13.63 \\
\hline $\begin{array}{lll}75 \% & \text { soil } & \mathrm{N}+3 \% \\
\text { urea } & & \\
\end{array}$ & 2.35 & 2.53 & 2.44 & 12.72 & 13.06 & 12.89 & 13.43 & 14.00 & 13.72 \\
\hline Mean & 2.31 & 2.48 & & 12.38 & 12.71 & & 13.07 & 13.76 & \\
\hline \multicolumn{10}{|l|}{ L S D $5 \%$} \\
\hline All treatments & 0.12 & 0.07 & & 0.23 & 0.29 & & 0.28 & 0.16 & \\
\hline Soil N & 0.08 & 0.06 & & 0.19 & 0.27 & & 0.20 & 0.15 & \\
\hline Foliar N & 0.05 & 0.04 & & 0.13 & 0.29 & & 0.14 & 0.10 & \\
\hline Interaction & n.s. & 0.08 & & n.s. & 0.26 & & n.s. & 0.21 & \\
\hline
\end{tabular}

However, application of $\mathrm{N}$ foliar spray on trees at a concentration of $3 \%$ urea with soil $\mathrm{N}$ dose increased growth parameters when compared with foliar of $1 \%$ urea with the same doses of soil $\mathrm{N}$ application. In addition, growth parameters were higher at $\mathrm{N}$ spraying of $3 \%$ urea with 50 and $75 \%$ of soil $\mathrm{N}$ dose compared to urea of $1 \%$ with the same previous doses of soil N. On the other hand, insignificant response was found in number of shoots/twig at the application of $3 \%$ urea foliar spray compared to $1 \%$ of foliar spray in the first season. Whereas, 
in the second season, urea of $3 \%$ foliar gave a significant number of shoots/twig parameter compared with $1 \%$ of foliar. However, the highest growth parameters were recorded from the trees sprayed with urea at $3 \%$ and $100 \%$ of soil $\mathrm{N}$ dose in the first and second seasons. In addition, the interaction between $\mathrm{N}$ application and growth parameters was significant in the second season compared to the first season. Moreover, in the second season, olive trees continued improving number of shoots per twig, shoot length and numbers of leaves per shoot compared with the first season. This may be due to efficiency of the foliar application is higher than that of soil one in these situations, because of the direct supply of the required nutrient to the location of demand in the leaves and its relatively quick absorption (Römheld and El-Fouly, 1999). Also, Mustafa et al. (2011) indicated that applying urea spray to olive seedlings was the most effective on growth performance. In this direction, Haggag (1996) showed that, on the addition the $\mathrm{N}$ requirements to Picual olive trees, growth parameter significantly responded to $\mathrm{N}$ fertilization. These results are in agreement with those of (Sanchez-Zamora and Fernandez-Escobar (2002) and Shufu et al. (2005).

\section{Fruit yield}

Data in Table 4 and Fig. 1 indicated that, the application of $\mathrm{N}$ fertilizer in all treatments significantly increased olive fruit yield compared with the control treatment. The results showed that the foliar application of $\mathrm{N}$ at the concentration of $1 \%$ and $3 \%$ urea gave insignificant increase in fruit yield compared to soil application of $\mathrm{N}$ alone. Combination of $1 \%$ or $3 \%$ urea with each of the $50 \%$ or $75 \%$ of $\mathrm{N}$ soil doses caused a significant increase in growth parameters but did not lead to a significant increase in fruit yield when compared to $\mathrm{N}$ soil alone. This may be due to insufficient supply of foliar $\mathrm{N}$ to trees compared to full dose of soil application. On the other hand, urea of 3\% sprayed with 50 and $75 \%$ of soil $\mathrm{N}$ dose increased significantly fruit yield compared to $1 \%$ of urea with the same doses. This may be due to response of trees to higher rate of $\mathrm{N}(3 \%)$. Moreover, application of urea sprayed of $1 \%$ with soil $\mathrm{N}$ doses significantly increased fruit yield compared to urea spraying of $3 \%$ with soil $\mathrm{N}$. This may be due to improvement of vegetative growth at the expense of yield fruiting. Hence, increasing of $\mathrm{N}$ may increase the vegetative growth which was negatively reflected on trees fruiting. In this direction, Dariusz (2004) observed that the highest dose of $\mathrm{N}$ application to apple trees reduced the number of fruits.

The above results assure role of integration between soil and foliar application in increasing fruit yield which was achieved at soil $\mathrm{N}$ does with sprayed of $1 \%$ urea. This could be due to enhancing increase the efficient use of $\mathrm{N}$ fertilizer by plant roots and leaves, especially through periods of critical requirement to this element, particularly in such a soil that has a low available $\mathrm{N}$ content, low organic matter and light texture as shown in Table 1. In addition, the integration of soil and foliar $\mathrm{N}$ applications may increase the efficiency of $\mathrm{N}$ used and reduces $\mathrm{N}$ loss (Khemira et al., 1998 and Abbasi et al., 2012). 
TABLE 4. Effect of $\mathbf{N}$ fertilization treatments on fruit yield and fruit oil percentage of Manzanillo olive trees.

\begin{tabular}{|l|l|l|l|l|l|l|}
\hline \multirow{2}{*}{ Treatments } & \multicolumn{2}{|c|}{ Fruit yield (Kg/tree) } & \multicolumn{2}{c|}{ Fruit oil percentage (\%) } \\
\cline { 2 - 7 } & $\begin{array}{c}\text { Season } \\
\mathbf{2 0 0 9}\end{array}$ & $\begin{array}{c}\text { Season } \\
\mathbf{2 0 1 0}\end{array}$ & Mean & $\begin{array}{c}\text { Season } \\
\mathbf{2 0 0 9}\end{array}$ & $\begin{array}{c}\text { Season } \\
\mathbf{2 0 1 0}\end{array}$ & Mean \\
\hline Control & 19.08 & 20.62 & 19.85 & 21.38 & 21.43 & 21.40 \\
\hline Soil N & 24.15 & 32.80 & 28.48 & 21.65 & 21.79 & 21.72 \\
\hline Foliar 1\% urea & 21.30 & 25.11 & 23.21 & 21.40 & 21.52 & 21.46 \\
\hline Soil N +1\% urea & 25.40 & 34.52 & 29.96 & 21.62 & 21.73 & 21.68 \\
\hline $50 \%$ soil N+1\% urea & 22.30 & 28.50 & 25.40 & 21.43 & 21.44 & 21.44 \\
\hline $75 \%$ soil N+1\% urea & 23.24 & 29.60 & 26.42 & 21.53 & 21.63 & 21.58 \\
\hline Foliar 3\% N urea & 19.78 & 27.25 & 23.51 & 21.56 & 21.69 & 21.62 \\
\hline Soil N +3\% urea & 22.42 & 28.46 & 25.44 & 21.52 & 21.63 & 21.58 \\
\hline $50 \%$ soil N+3\% urea & 23.39 & 30.03 & 26.71 & 21.45 & 21.56 & 21.50 \\
\hline $75 \%$ soil N+3\% urea & 24.50 & 31.01 & 27.75 & 21.55 & 21.65 & 21.60 \\
\hline Mean & 22.56 & 29.25 & & 21.51 & 21.61 & \\
\hline L S D 5\% & \multicolumn{7}{|l|}{} & & & \\
\hline All treatments & 0.77 & 0.56 & & 0.05 & 0.07 & \\
\hline Soil N & 0.76 & 0.51 & & 0.06 & 0.04 & \\
\hline Foliar N & 0.36 & 0.36 & & & & \\
\hline Interaction & 1.07 & 0.72 & & & \\
\hline
\end{tabular}

Moreover, fruit yield load in the second season was higher than the first season and continued to increase in all treatments following the same trend but producing greater fruiting. This could be due to an increase in available soil $\mathrm{N}$ content, which was low in the soil (Table 1). Also, the increase in yield due to spraying of water soluble fertilizer plus emulsifier which increase absorb of nutrients and water resulting in more photosynthesis and better response. Our findings agreed with those obtained by Mengel and Kirby (1987), Abd El-Rhman (2002) and Abou-Amer (2007).

Oil yield

From data in Table 4 and Fig. 1 results showed that, applications of $\mathrm{N}$ to the trees had a significant increase in the oil percentage or oil yield compared to the control treatment. In this respect, applied foliar $\mathrm{N}$ at rates $1 \%$ and $3 \%$ urea insignificantly increased oil yield compared to $\mathrm{N}$ soil application alone. Whereas, oil yield increased significantly when adding $\mathrm{N}$ spray of $3 \%$ urea compared to spray of $1 \%$ urea. In this direction, Inglese et al. (2002) showed that effects of applying 2\% urea and potassium, applied as foliar fertilizers, reduced fruit drop and improved oil yield. On the other hand, increased of oil yield at the application of $3 \%$ urea with 50 and $75 \%$ of soil $\mathrm{N}$ dose compared to $1 \%$ of urea with the same doses was insignificant. Moreover, soil application of $\mathrm{N}$ dose had significantly increased oil yield compared with all treatments. In addition, similar trends were obtained of fruit oil production in the first and second seasons. In this respect, Amit-Jasrotia et al. (1999) indicated that oil content of 
olive trees increased significantly as the $\mathrm{N}$ application rate increased. Also, Haggag (1996) observed the effect $\mathrm{N}$ application to Picual olive trees and increased oil content of fruits compared with the control trees. These results are in harmony with those obtained by Abdel-Hameed (2002), Abd El-Rhman (2002) and Abou-Ameer (2007).

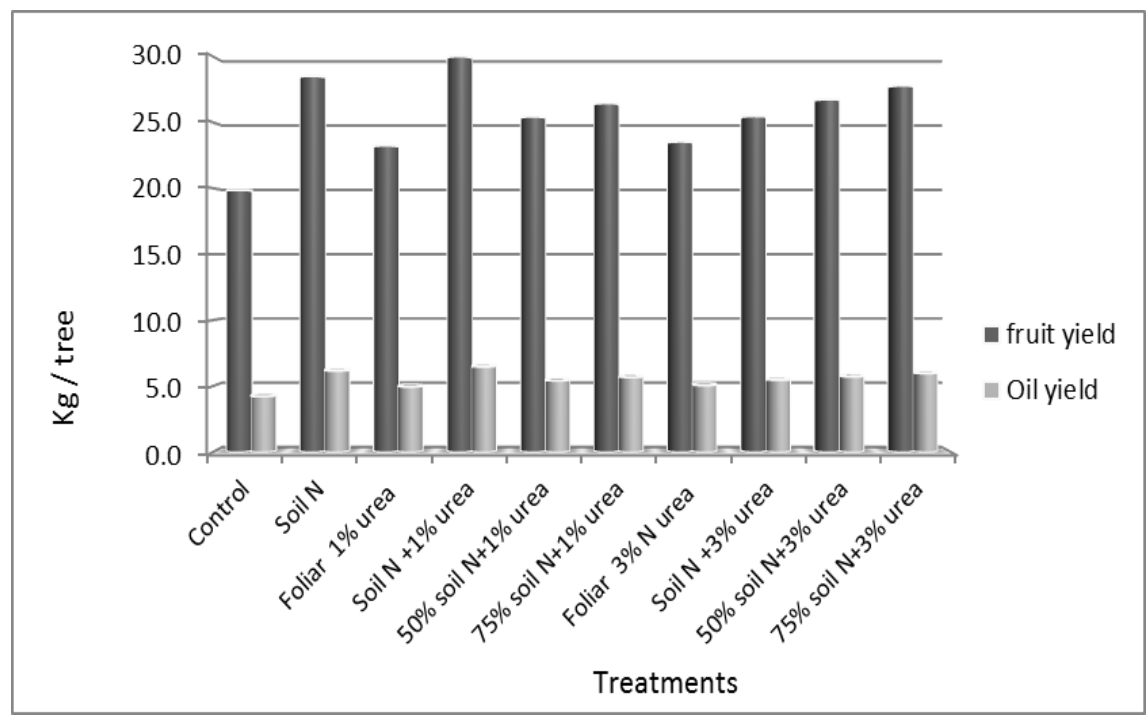

Fig. 1. Effect of $\mathrm{N}$ fertilizer treatments on fruit and oil yields ( $\mathrm{kg} / \mathrm{tree})$ of Manzanillo olive trees average of two seasons.

\section{$N$ mineral content of olive leaves}

Date in Table 5 showed the response of olive trees to the different rates and methods of $\mathrm{N}$ application used during the two seasons. The concentration of $\mathrm{N}$ in leaves was significantly higher in trees that received either soil or foliar $\mathrm{N}$ applications than in control trees. Also, soil of $\mathrm{N}$ application significantly increased concentration of $\mathrm{N}$ than the foliar of $\mathrm{N}$ applications of $1 \%$ and $3 \%$ urea. This could be due to increased available soil $\mathrm{N}$ content compared with foliar $\mathrm{N}$ application. However, the concentration of $\mathrm{N}$ was high at urea spraying of $3 \%$ urea with 50 and $75 \%$ of soil $\mathrm{N}$ dose compared to urea of $1 \%$ with the same rates of soil $\mathrm{N}$ doses. This may be attributed to increase of $\mathrm{N}$ application to the soil and spray on trees of $3 \%$ compared to urea of $1 \%$. In this respect Sanchez and Fernandez (2002) who reported that, leaf $\mathrm{N}$ concentration significantly increased when urea was applied to both soil and leaves as compared to only soil application. Also, Connell et al. (2002) found that, the foliar urea spray significantly increased leaf $\mathrm{N}$ levels. On the other side, in the second season, there were no significant differences in $\mathrm{N}$ concentration when applied $\mathrm{N}$ soil dose with urea spray of $3 \%$ compared to apply of $\mathrm{N}$ soil dose with $1 \%$ urea. This may be due to soil $\mathrm{N}$ with $3 \%$ foliar treatment caused an increase in vegetative parameters of trees and dilution effect. In addition, the same trends

Egypt. J. Soil Sci. 53, No.2 (2013) 
were observed in $\mathrm{N}$ concentration and it was higher than the first season. These results were similar to those obtained by Abou-Rawash et al. (2010) who found that, in the second season, the $\mathrm{N}$ content was higher than the first season of Picual olive trees.

TABLE 5. Effect of $\mathrm{N}$ fertilization treatments on leaves and soil mineral content of Manzanillo olive.

\begin{tabular}{|c|c|c|c|c|c|c|c|c|}
\hline \multirow{3}{*}{ Treatments } & \multicolumn{3}{|c|}{ Leaf $N \%$} & \multicolumn{5}{|c|}{ Soil N (mg/kg $\left.{ }^{-1}\right)$} \\
\hline & \multirow{2}{*}{$\begin{array}{c}\text { Season } \\
2009\end{array}$} & \multirow{2}{*}{$\begin{array}{c}\text { Season } \\
2010\end{array}$} & \multirow{2}{*}{ Mean } & \multicolumn{2}{|c|}{ Season 2009} & \multicolumn{2}{|c|}{ Season 2010} & \multirow{2}{*}{ Mean } \\
\hline & & & & $\begin{array}{c}\mathbf{0 - 3 0} \\
\mathbf{c m} \\
\end{array}$ & $\begin{array}{c}30-60 \\
\mathrm{~cm}\end{array}$ & $\begin{array}{c}\mathbf{0 - 3 0} \\
\mathbf{c m} \\
\end{array}$ & $\begin{array}{c}30-60 \\
\mathrm{~cm}\end{array}$ & \\
\hline Control & 1.00 & 1.05 & 1.02 & 12.25 & 5.00 & 14.23 & 5.60 & 9.27 \\
\hline Soil N & 1.80 & 1.99 & 1.90 & 23.20 & 8.60 & 32.30 & 10.20 & 18.58 \\
\hline Foliar $1 \%$ urea & 1.79 & 1.85 & 1.82 & 18.50 & 8.00 & 23.73 & 9.30 & 14.88 \\
\hline Soil $\mathrm{N}+1 \%$ urea & 1.87 & 2.02 & 1.95 & 23.75 & 9.00 & 32.64 & 10.60 & 19.00 \\
\hline $50 \%$ soil $\mathrm{N}+1 \%$ urea & 1.65 & 1.79 & 1.72 & 20.35 & 8.22 & 24.30 & 9.50 & 15.59 \\
\hline $75 \%$ soil $\mathrm{N}+1 \%$ urea & 1.68 & 1.88 & 1.78 & 22.80 & 8.50 & 28.20 & 10.00 & 17.38 \\
\hline Foliar $3 \% \mathrm{~N}$ urea & 1.78 & 1.93 & 1.85 & 19.30 & 8.20 & 24.10 & 9.20 & 15.20 \\
\hline Soil $\mathrm{N}+3 \%$ urea & 2.04 & 2.02 & 2.03 & 23.50 & 8.80 & 31.53 & 10.70 & 18.63 \\
\hline $50 \%$ soil $\mathrm{N}+3 \%$ urea & 1.70 & 1.86 & 1.78 & 21.40 & 8.30 & 28.00 & 9.60 & 16.83 \\
\hline $75 \%$ soil $\mathrm{N}+3 \%$ urea & 1.78 & 1.91 & 1.85 & 23.20 & 8.50 & 30.20 & 10.10 & 18.00 \\
\hline Mean & 1.71 & 1.83 & & 20.83 & 8.11 & 26.92 & 9.48 & \\
\hline \multicolumn{9}{|l|}{ LSD $5 \%$} \\
\hline All treatments & 0.08 & 0.04 & & 0.62 & 0.97 & 0.63 & 0.99 & \\
\hline Soil N & 0.08 & 0.03 & & 0.32 & n.s. & 0.43 & 0.89 & \\
\hline Foliar N & 0.08 & 0.03 & & 0.23 & n.s. & 0.30 & n.s. & \\
\hline Interaction & 0.07 & 0.03 & & 0.45 & n.s. & 0.61 & n.s. & \\
\hline
\end{tabular}

$N$ mineral content of soil

The data presented in Table 5 revealed that, mineral content of soil was increased by $\mathrm{N}$ compared to control treatment. Also, the highest soil $\mathrm{N}$ content was recorded by soil application. Soil $\mathrm{N}$ content increased significantly in the surface soil layer in second season then the first season, but no significant difference was observed on soil $\mathrm{N}$ subsurface in both seasons. This may be due to high $\mathrm{N}$ uptake efficiency in the root zone and increasing growth of roots trees may be led to reduce loss of $\mathrm{N}$ by leaching, and also, due to low content of $\mathrm{N}$ and organic matter of the soil, as shown in Table 1. Moreover, applied of $\mathrm{N}$ as soil application treatment had a significant increase in the soil $\mathrm{N}$ content compared to applied of $50 \%$ or $75 \%$ of soil $\mathrm{N}$ doses and foliar application either 
urea of $1 \%$ and or of $3 \%$ treatments. This could be due to full dose of soil $\mathrm{N}$ compared to other treatments with low soil $\mathrm{N}$ to $50 \%$ or $75 \%$ application and $\mathrm{N}$ foliar applied. Moreover, similar trends were observed in increased soil $\mathrm{N}$ content in the second season compared to first season. These results agreed with those obtained by Abou-Amer (2007).

In conclusion, the optimum fertilizer treatment was the integrated soil application dose with foliar at $1 \% \mathrm{~N}$ resulted in increased plant growth, fruit yield and oil content as well as $\mathrm{N}$ uptake. So, it could be recommended to use integrated of $800 \mathrm{~g} \mathrm{~N} /$ tree as soil application with urea foliar spray of $1 \%$ for Manzanillo olive trees in a similar soils under Siwa Oasis conditions.

\section{References}

Abbasi, Y., Bakhshi, D., Forghani, A., Sabouri, A. and Porghauomy, M. (2012) Effect of macro and micronutrients sprays on fruit quality and quantity of 'Zard' and 'Rowghani' olive (Olea europaea L.) cultivars in Northern Iran. American-Eurasian J. Agric. \& Environ. Sci. 12 (12): 1548-1552.

Abd El-Rhman, A.E. M. (2002) Response of olive trees to fertilization under rainfed conditions. Ph.D. Thesis, Fac. of Agric., Moshtohor (Benha branch), Zagazig Univ.

Abdel-Hameed, A. A. (2002) Response of Manzanillo olive trees to nitrogen biofertilizer under northern western coast condition. M. Sc. Thesis, Fac. Agric., Cairo Univ.

Abou-Rawash, M., El-Wakeel, H. Laila, Hagag, F., Hassan, H. S. A. and AbdelGalel, A.(2010) Response of Picual olive young trees to mineral, organic nitrogen fertilization and some other treatments. Journal of American Science 6 (12).

Abou-Amer, A.I. (2007) Nutritional status and fertilizer requirements for some fruit trees in Siwa Oasis. Ph.D. Thesis, Fac. of Agric, Tanta, Tanta Univ.

Amit-Jasrotia, Singh, R. P., Singh, J. M., Bhutani, V.P., Jasrotia, A., Metzidakis, I. T. and Voyiatzis, D. G. (1999) Response of olive trees to varying level of $\mathrm{N}$ and $\mathrm{K}$ fertilizer. Acta Horticulturae (474):337-340.

AOAC (2000) "Official Methods of Analysis", $17^{\text {th }}$ ed., William Horwitz (Ed.), Association of Official Analytical Chemists, Arlington Virginia, USA.

Black, C.A., Evans, D.D.,White, J.I., Ensminger, L.E. and Clark, F.E. (1982) "Methods of Soil Analysis", Amer. Soc. Agronomy Inc., Publisher Madison, Wisconsin, U.S.A.

Bondada, B.R., Syvertsen, J.P. and Albrigo, L.G. (2001) Urea nitrogen uptake by citrus leaves. Hort. Science 36:1061-1065.

Connell, J.H., Krueger, W.H., Ferguson, L., Metheney, P.D., Reyes, H. and Sibbett, G.S. (2002) Effects of foliar application of urea on olive leaf nitrogen, growth and yield. Acta Hort. 586: 51 - 254 .

Egypt. J. Soil Sci. 53, No.2 (2013) 
Dariusz, W. (2004) Effect of nitrogen fertilization on growth, cropping and fruit quality of 'Šampion' apple trees during 9 years after planting. Folia Horticulture Ann. 16(1): 55-60.

Dinnes, D.L., Karlen, L., Jaynes, D.B., Kaspar, T.K., Hatfield, J.L., Colvin, T.S. and Cambardella, C.A (2002) Nitrogen management strategies to reduce nitrate leaching in tile-drained Midwestern soils. Agron. J. 94: 153-171.

Fernandez-Escobar, R. and Marin, L. (1999) Nitrogen fertilization in olive orchards. Acta-Horticulturae (474): 333-335.

Gomez, K.A. and Gomez, A.A. (1984) "Statistical Procedures for Agricultural Research", $2^{\text {nd }}$ ed., Wiley, New York.

Haggag, L. F. (1996) Response of Picual olive trees in sandy soil to various forms of $\mathrm{N}$ fertilizer (organic and inorganic). Annals of Agric. Sci. Cairo 41 (1): 313-319.

Hegazi, E.S., El-Sonbaty, M.R., Eissa, M.A., Dorria, M.Ahmed and El-Sharony, T.F. (2007) Effect of organic and bio-fertilization on vegetative growth and flowering of Picual olive trees. World J. of Agric. Sci. 3(2): 210-217.

Inglese, P., Gullo, G. and Pace, L. S. (2002) Fruit growth and olive oil quality in relation to foliar nutrition and time of application. Acta-Horticulturae (586): 507-509.

Khemira, H., Righetti, T.L. and Azarenko, A.N. (1998) Nitrogen partitioning in apple as affected by timing and tree growth habit. J. Horticultural Sci. Biotechnol. 73: 217-223.

López-Granados, F., Jurado-Expósito, M., Álamob, S., Garc'ıa-Torres, L. (2004) Leaf nutrient spatial variability and site-specific fertilization maps within olive (Olea europaea L.) orchards. Europ. J. Agronomy 21: 209-222.

Mengel, K. (2002) Alternative or complementary role of foliar supply in mineral nutrition of plants. Acta - Horticulturae (594): 33-47.

Mengel, K. and Kirby, E.A. (1987) "Principles of Plant Nutrition", pp.1-50, International Potash Institutes Bern, Switzerland.

Mustafa, N.S., Laila, F. Hagag, Shahin, M.F.M. and Eman, S. El-Hady (2011) Effect of spraying different $\mathrm{n}$ sources on growth performance of Picual olive seedlings. American-Eurasian J. Agric. \& Environ. Sci. 11 (6): 911-916, Nutrition and time of application. Acta Hort. (586): 507-509.

Osman, S. M. (2010) Effect of mineral, bio-npk soil application of young olive trees and foliar fertilization on leaf and shoot chemical composition. Research Journal of Agriculture and Biological Sciences 6 (3): 311-318.

Pastor, M. (2005) Cultivo del olivo con riego localizado. Consejería de Agricultura y Pesca de la Junta de Andalucía y Mundi-Prensa. Madrid.

Payvandi, M., Dadashian, A., Ebrahimzadeh, H. and Madjd, A. (2001) Embryogenesis and rhizogenesis in mature zygotic embryos of olive (Olea europaea L.) cultivars Mission and Kroneiki. J. Sci. IR Iran 12 (1): 9-15. 
Römheld, V. and El-Fouly, M.M. (1999) Foliar nutrient application: challenge and limits in crop production. Proc. of the $2^{\text {nd }}$ International Workshop on Foliar Fertilization, April 4-10, 1999, pp: 1-34, Bangkok, Thailand,

Rosecrance, R.C., Johnson, R.S. and Weinbaum, S.A. (1998) The effect of timing of post-harvest foliar urea sprays on nitrogen absorption and partitioning in peach and nectarine trees. J. Horticultural Sci. Biotechnol. 73: 856-861.

Sanchez-Zamora, M. A. and Fernandez-Escobar, R. (2002) The effect of foliar vs. soil application of urea to olive trees. Acta-Horticulturae (594): 675-678.

Shufu, D., Lailiang Cheng, C. F., Carolyn, F. S. and Leslie, H. (2005) Method of nitrogen application in summer affects plant growth and nitrogen uptake in autumn in young Fuji/M.26 Apple trees. Soil Science and Plant Analysis 36: 1465-1477.

(Received 13/11/2012;

accepted $20 / 2 / 2014$ ) 


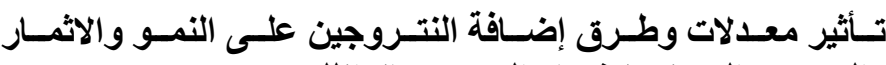 والمحتوى المعدنى لاشجار الزيتون مانزانللو}

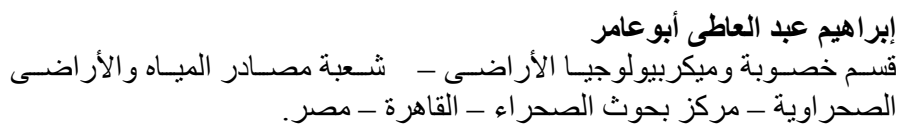

أجريت تجربة حقلية في منطقة بير الكاف غرب واحة سيوة (عند الأحداثيات

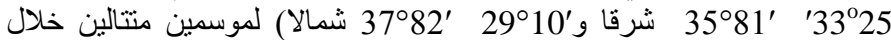

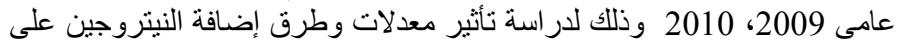

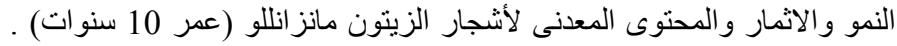

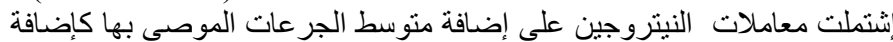

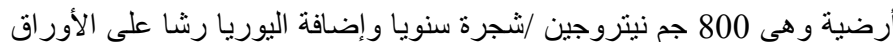

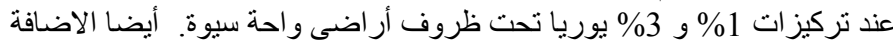

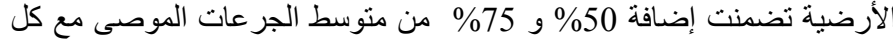

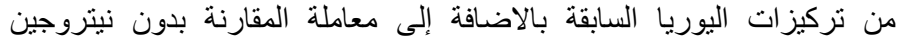

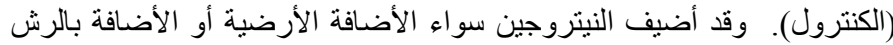

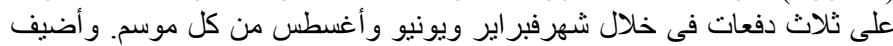

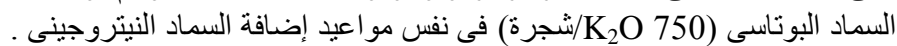
كما أضيف الفوسفور (300جم

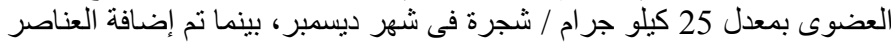

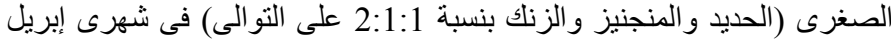

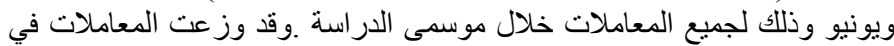
تصميم كامل العشوائية مع ثلاث مكرر اتلات خلكل معلى معاملة.

وقد أظهرت النتائج إستجابة أشجار الزيتون معنويـا لجميع معاملات التسميد

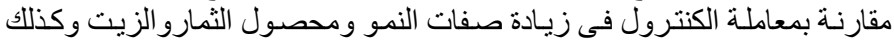

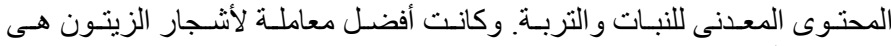

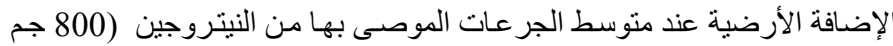

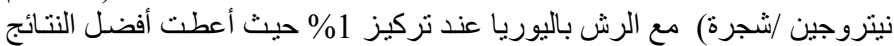

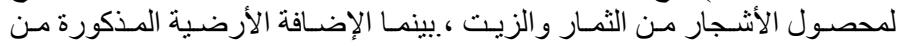

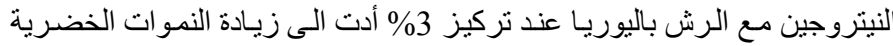

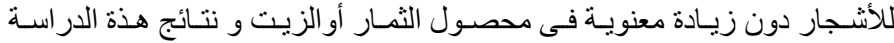

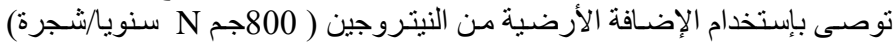

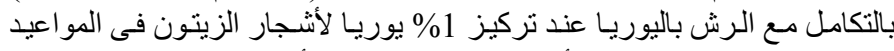

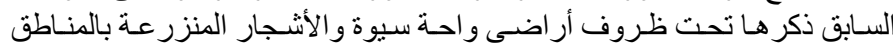

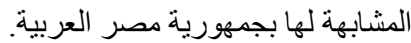

